\title{
Effect of some Essential Oils of Zingiberaceae Family on Pathogenic Bacteria Content in Minced Meat
}

\author{
Amany Ahmed Abd El-Aziz \\ Home Economics Department, Faculty of Specific Education, South Valley \\ University, Qena, Egypt
}

\begin{abstract}
Meat and its products such as minced meat are highly perishable and can spoil very easily if they are not store properly. Pathogens bacteria such as Sylococcus aureus and Escherichia coli were the most bacteria caused meat spoilage. Essential oils and their extracts can be used to extend the shelf life of meat and their products and control/inhibit the microbial growth. In the current study, the essential oils of three species of Zingiberaceae family, (ginger, galangal and turmeric) were extracted to investigate and compare their chemical compositions and study their effect on control/inhibit the growth of pathogenic bacteria in minced meat. Samples of fresh rhizomes of ginger, galangal and turmeric were purchased from Qena governorate local market during spring 2018. Proximate chemical analysis and total antioxidant content of samples were determined. Effect of different concentrations of $1,1.5$ and $2 \%$ of ginger, galangal and turmeric essential oils on pathogenic bacteria content in minced meat during cold storage at $2^{\circ} \mathrm{C}$ for 10 days was investigated. The obtained results showed that ginger had the highest content of moisture, protein and ash. Galangal scored the highest content of total fiber, while turmeric recorded the highest level of fat and carbohydrates. Total phenolic \& flavonoid content of ginger, galangal and turmeric were 39.6 and $18.61 ; 34.96$ and 19.37 ; and 41.40 and $18.97 \mathrm{mg} / \mathrm{g}$, respectively. Also, decreased both of aerobic plate count, Sylococcus aureus count and E. coli count in treated minced meat with herbs extracts than control samples all over the period of experiment were observed. Whereas there were significant differences between control minced meat and all treated minced meat with herbs extracts at $\mathrm{p}<0.05$ level. The $\mathrm{pH}$ values of control samples were higher than samples treated with ginger, galangal and turmeric all over the experiment. Additionally, the mean of $\mathrm{pH}$ values of treated samples decreased as concentrations of essential oil increased. Essential oil extracted from ginger was the most efficient on Sylococcus aureus count than that of essential oil extracted from galangal and turmeric, while essential oil extracted from turmeric was the most efficient on E. coli count than that of essential oils extracted from ginger and galangal. It could be concluded that essential oil from Zingiberaceae family such as ginger, galangal and turmeric were considered as efficient antimicrobial agents for preserving meat and its products and extending their shelf life.
\end{abstract}

Key words: Essential oils, extracts, ginger, galangal, turmeric, total phenolics, microbial content, minced meat.

\section{Introduction}

Meat has a short shelf life of one day or less at ambient temperature $\left(15-30^{\circ} \mathrm{C}\right)$ and a few days at refrigerated temperature $\left(0-10^{\circ} \mathrm{C}\right)$ due to their microbial spoilage of both pathogenic and non-pathogenic microorganisms and/or lipid oxidation (Salem et al., 2017). Studies on the microbiological quality of food shows that minced meat is a medium rich in nutrients required for the growth of pathogenic microorganisms (EImalı and Yaman, 2005; Norman and Gravani, 2006). It has been known as a vehicle for transmission of organisms such as E. coli and S. aureus (Bell, 1997).

Escherichia coli is a gram negative bacterium. It is subtype and may vary widely contaminated in ecosystem. Contaminated both water and then to contaminate the food. In human it is a common inhabitant of the gastrointestinal tract. It can also 
cause various intestinal which can develop to extra-intestinal diseases (Nelson $\boldsymbol{e t}$ al., 2008).

Sylococcus aureus is nonspore forming Gram-positive cocci, which in some strains, are able to produce an enterotoxin (Oonmetta-aree et al., 2006; Vanderzant and Splittstoesser, 1992). Although, several synthetic food additives have been widely used in the meat industry to extend food shelf life, inhibit lipid oxidation and delay or inhibit the growth of pathogenic microorganisms, the trend is to decrease their use because of the growing concern among consumers about such chemical additives.

Phenolic compounds were the main contributor of antioxidant activity in plants (Maizura et al., 2011). They were considered as an important class of antioxidant due to their radical scavenging activity via hydrogen atom donation. Plants of the family Zingiberaceae comprises about 1400 species. The main zingiberaceous genera are Alpinia, Amomum, Curcuma, Elettaria, Hedychium, Kaempferia and Zingiber (Tripathi et al., 2013). Spices and herbs are an excellent source of phenolic compounds (flavonoids, phenolic acid and alcohols, stilbenes, tocopherols, tocotrienols), ascorbic acid and carotenoids which have been reported to show good antioxidant activity (Zheng and Wang, 2001). Zingiberaceae plants contain many essential oils, including terpenes, alcohols, ketones, tannins, flavonoids, carotenoids and phytoestrogens (Habsah et al., 2000; Matsuda et al., 2002; Suhaj, 2006). They have been reported for their biological activities in antifungal, antioxidant, insecticidal, and anti-inflammatory activities, Ginger (Zingiber officinale) has been used as a spice and as natural additives for more than 2000 years (Bartley and Jacobs, 2000). Galangal (Alpinia galanga) is used to flavor foods. Its rhizome has a wide range of applications in traditional medicine, as the essential oil shows an antimicrobial activity (Yang and Eilerman, 1999). Turmeric (Curcuma longa L.) belongs to the Zingiberacea family reported to possess numerous medicinal properties including antioxidant activity (Pulla and Lokesh, 1992). So, the current study was conducted to evaluate the effect of essential oils of the three species from Zingiberaceae family (ginger, galangal and turmeric) on control/inhibit the growth of pathogenic bacteria in minced meat.

\section{Materials and Methods Materials}

Samples of fresh rhizomes of ginger (Zingiber officinale), galangal (Alpinia galangal) and turmeric (Curcuma longa) each of weighed (3.5-5 $\mathrm{kg}$ ) were obtained from Qena governorate local market during spring 2018.

Minced meat was purchased from Qena Governorate local markets. Meats were divided into 13 groups, one group was left as untreated groups (control), and the treated groups were treated with $(1,1.5$ and $2 \%)$ concentrations of each essential oil (ginger, turmeric and galangal). All samples were kept in polyethylene film and stored at cold storage $2^{\circ} \mathrm{C}$ for 10 days. All samples were analyzed in triplicate for proximate composition, total phenolic, total flavonoids, tannins and saponins. Samples were investigated bacteriologically for aerobic plate count, (Sylococcus aureus and E. coli count) during storage at cold storage $2^{\circ} \mathrm{C}$ for 10 days. 


\section{Amany A. Abd El-Aziz}

\section{Methods}

Proximate chemical analysis

All samples of fresh rhizomes of ginger, galangal and turmeric were analyzed in triplicate for moisture, protein ( $\mathrm{TN} \times 6.25$, micro - kjeldahl method using semiautomatic apparatus, Velp company, Italy ), fat (soxhelt semiautomatic apparatus Velp company, Italy, petroleum ether solvent), ash and fiber contents were determined using the methods described in the AOAC. (2010). Carbohydrates calculated by differences:

Carbohydrates $(\%)=100-(\%$ moisture $+\%$ protein $+\%$ fat $+\%$ Ash $+\%$ fiber $)$

\section{Determination of $\mathrm{pH}$ value}

The $\mathrm{pH}$ value was determined by blending $10 \mathrm{~g}$ of the homogenized sample with $90 \mathrm{ml}$ distilled water (Kirk and Sawyer, 1991) and measuring using a $\mathrm{pH}$ meter (Model No. pH-8414).

\section{Preparation of extracts}

Fresh rhizomes of ginger, galangal and turmeric were cleaned, sliced and dried by the oven drying methods at $60^{\circ} \mathrm{C}$ for 24 hours. After drying, samples were blended to turn into powder. The powder of sample was kept in polyethylene film and stored till used.

\section{Hydro-alcoholic extractions}

The extraction procedure for the hydro-alcoholic extract was carried out according to Charles et al., (1993) method.

\section{Determination of total phenolic compound}

Total phenolic content was measured by using Folin's reagent according to method of AOAC (2000).

\section{Determination of total flavonoids}

The flavonoids content was determined by method described by Zhishen $\boldsymbol{e t}$ al., (1999).

\section{Determination of tannins}

Total tannins were determined according to method of Rajeev et al., (2012).

\section{Determination of saponins}

Total saponins were determined as described by Edeoga et al., (2005).

\section{Microbiological examination Preparation of samples}

Ten grams of each sample were weighted and placed in a $250 \mathrm{ml}$ sterilized conical flask containing $90 \mathrm{ml}$ of $0.1 \%$ peptone water to make a dilution of $10^{-1}$. The flasks were then shaken well for 10 minutes. One $\mathrm{ml}$ of the diluted sample was added to $9 \mathrm{ml}$ of sterilized peptone water in tube using sterilized pipettes. This was shaken vigorously 25 times. Further dilutions were made using the same procedure to prepare dilutions of $10^{-1}$ to $10^{-7}$. The pervious dilutions were used for the following determination:

\section{Determination of total aerobic plate count (APC)}

One $\mathrm{ml}$ of each diluted samples were using sterilized basal media (in an autoclave at $121^{\circ} \mathrm{C}$ for 15 minutes) following the procedure proposed by International Commission on Microbiological Specifications for foods (ICMSF, 1996). 


\section{Amany A. Abd El-Aziz}

\section{Determination of $E$. coli count}

The total E. coli count was determined according to the method of the International Commission on Microbiological Specifications for Foods (ICMSF, 1996).

\section{Determination of Sylococcus aureus count}

The total $S$. aureus count was determined according to the method of the International Commission on Microbiological Specifications for Foods (ICMSF, 1996).

\section{Statistical analysis}

The methods of statistical analysis were done using SPSS: analysis without anguish version 12.0 for windows (Coakes, 2005). One Way ANOVA to detect the significant differences between the three treated groups (ginger, galangal and turmeric) (Dowdy et al., 2004). Duncan Multiple Comparison to recognize the significant differences between averages of counts of bacteria in different samples (El-Sherbeeny, 1995). The results were expressed as mean \pm standard deviation.

\section{Results and Discussion}

Chemical composition of ginger, galangal and turmeric dried rhizomes powder

Data in Table (1) showed that mean moisture content of ginger, galangal and turmeric was $10.35 \pm 0.062,9.55 \pm 0.045$ and $9.23 \pm 0.026 \%$; respectively. The highest protein content was scored by ginger $8.5 \pm 0.045 \%$, followed by galangal which contained $7.64 \pm 0.13 \%$, while, the percentage of protein in turmeric was $7.07 \pm 0.02 \%$. There was a significant difference between ginger and other plants in protein content at $(\mathrm{p}<0.05)$. Turmeric had the highest level of fat $4.74 \pm 0.66 \%$, whilst, the lowest fat level was in ginger $1.74 \pm 0.09 \%$, there was significant decrease in ginger fat content compared with galangal and turmeric. As observed from Table (4) galangal had the highest level of crude fiber $7.88 \pm 0.62 \%$. The means of ash content in ginger, galangal and turmeric were $4.7 \pm 0.001,2.89 \pm 0.020$ and $4.43 \pm 0.007 \%$; respectively. At last, the means of carbohydrate content in ginger, galangal and turmeric was $68.91 \pm 0.146,67.85 \pm 0.159$ and $70.82 \pm 0.23 \%$; respectively. Such results were similar with those obtained by (El-Ghorab et al., 2010; Mohd et al., 2003; Turker and Usta, 2006), but these results were disagreed with those obtained by (Adel and Prakash, 2010; Fattepurkar et al., 2009; Hussain et al., 2009; Noheer, 2018).

Table (1): Mean of chemical composition of ginger, galangal and turmeric dried rhizomes powder

\begin{tabular}{c|c|c|c|c|c|c}
\hline Sample & Moisture\% & Protein\% & Fats\% & Crude Fibers\% & Ash\% & Carbohydrates \% \\
\hline Ginger & $10.35 \pm 0.062^{\mathrm{a}}$ & $8.5 \pm 0.045^{\mathrm{a}}$ & $1.74 \pm 0.09^{\mathrm{b}}$ & $5.8 \pm 0.26^{\mathrm{b}}$ & $4.7 \pm 0.001^{\mathrm{a}}$ & $68.91 \pm 0.146^{\mathrm{b}}$ \\
\hline Galangal & $9.55 \pm 0.045^{\mathrm{b}}$ & $7.64 \pm 0.13^{\mathrm{b}}$ & $4.19 \pm 0.38^{\mathrm{a}}$ & $7.88 \pm 0.62^{\mathrm{a}}$ & $2.89 \pm 0.020^{\mathrm{b}}$ & $67.85 \pm 0.159^{\mathrm{b}}$ \\
\hline Turmeric & $9.23 \pm 0.026^{\mathrm{b}}$ & $7.07 \pm 0.02^{\mathrm{b}}$ & $4.74 \pm 0.66^{\mathrm{a}}$ & $3.69 \pm 0.13^{\mathrm{c}}$ & $4.43 \pm 0.007^{\mathrm{a}}$ & $70.82 \pm 0.23^{\mathrm{a}}$ \\
\hline
\end{tabular}

Data followed by different letters in the same column are significantly different at $p \leq 0.05$

Total antioxidant content of ginger, galangal and turmeric extractions 
Antioxidants in such studied plants included phenolic, flavonoids, carotenoids, tannins and saponins. Results of total phenolic content were presented as milligrams of gallic acid equivalent (GAE) per one gram of dry extract. Data in Table (2) showed that the mean of total phenolic compounds in ginger, galangal and turmeric extracts were $39.6 \pm 2.02,34.9 \pm 1.26$ and $41.4 \pm 2.46 \mathrm{mg}$ GAE$/ \mathrm{g}$; respectively. Such result was closed with that obtained by Rababah et al., (2004) who showed that total phenolic content in ginger was $39.9 \mathrm{mg} / \mathrm{g}$. There was a significant difference between total phenolic content of galangal extract and both these of ginger and turmeric at $(\mathrm{P}<0.05)$. Total flavonoids compound in ginger, galangal and turmeric extracts were $18.61 \pm 0.98, \quad 19.37 \pm 1.11$ and $18.97 \pm 0.28 \mathrm{mg} / \mathrm{g}$; respectively. Tannins were considered antimicrobial substances. Ginger had the lowest level of tannins $(10.37 \pm 0.05 \mathrm{mg} / \mathrm{g})$. Ekop et al., (2010) reported that the trace level of tannins in ginger rhizome is therefore considered to be below toxic level in animals. The levels of tannins in galangal and turmeric were $14.27 \pm 1.13$ and $13.06 \pm 1.01 \mathrm{mg} / \mathrm{g}$; respectively. Such results were similar with that were obtained by Noheer, (2018). Saponins have been reported to have antimicrobial properties and they may act as important precursor for steroidal substances. These steroidal substances have wide range of pharmacological activities (Hashemi et al., 2008). Results showed that the mean of saponins in ginger, galangal and turmeric extracts were $11.82 \pm 0.32,11.12 \pm 1.09$ and $10.42 \pm 0.62 \mathrm{mg} / \mathrm{g}$; respectively. Johnson et al., (1986) stated that plants with high concentrations of saponins improve the growth of beneficial gastrointestinal micro flora and the permeability of the mucosal cells of the small intestine, thereby facilitating the uptake of nutrients.

Table (2): Mean values of total antioxidant content of ginger, galangal and turmeric extractions

\begin{tabular}{c|c|c|c|c}
\hline Sample & $\begin{array}{c}\text { Total phenolic mg } \\
\text { GAE/g }\end{array}$ & $\begin{array}{c}\text { Total flavonoid } \\
\mathrm{mg} / \mathrm{g}\end{array}$ & $\begin{array}{c}\text { Tanins } \\
\mathrm{mg} / \mathrm{g}\end{array}$ & $\begin{array}{c}\text { Saponins } \\
\mathrm{mg} / \mathrm{g}\end{array}$ \\
\hline Ginger & $39.6 \pm 2.02^{\mathrm{a}}$ & $18.61 \pm 0.98^{\mathrm{b}}$ & $10.37 \pm 0.05^{\mathrm{b}}$ & $11.82 \pm 0.32^{\mathrm{a}}$ \\
\hline Galangal & $34.9 \pm 1.26^{\mathrm{b}}$ & $19.37 \pm 1.11^{\mathrm{a}}$ & $14.27 \pm 1.13^{\mathrm{a}}$ & $11.12 \pm 1.09^{\mathrm{a}}$ \\
\hline Turmeric & $41.4 \pm 2.46^{\mathrm{a}}$ & $18.97 \pm 0.28^{\mathrm{ab}}$ & $13.06 \pm 1.01^{\mathrm{a}}$ & $10.42 \pm 0.62^{\mathrm{b}}$ \\
\hline
\end{tabular}

Data followed by different letters in the same column are significantly different at $\mathrm{p} \leq 0.05$

\section{Effect of different concentrations of (ginger, galangal and turmeric) essential oils on $\mathrm{pH}$ values of untreated and treated samples}

Meat $\mathrm{pH}$ changes with the increasing bacterial population, Shelef and Jay, (1970) reported that the $\mathrm{pH}$ of beef rose with increasing bacterial growth. Kesavan et al., (2014) reported that increasing meat $\mathrm{pH}$ reflects the degree of meat spoilage through protein breakdown for the production of free amino acids, leading to the formation of $\mathrm{NH}_{3}$ and amines, compounds of alkaline reactions. Data in Table (3) showed that $\mathrm{pH}$ values of all samples of minced meat at the beginning of the experiment were 5.5 \pm 0.01 . The mean of $\mathrm{pH}$ values of control samples in $3^{\text {rd }}, 5^{\text {th }}, 7^{\text {th }}$ and $10^{\text {th }}$ day were $5.97 \pm 0.002$, $6.31 \pm 0.02,6.65 \pm 0.007$ and $6.82 \pm 0.19$; respectively. The mean of $\mathrm{pH}$ values of samples treated with $1,1.5$ and $2 \%$ ginger oil in $10^{\text {th }}$ day were $6.43 \pm 0.02$, $6.22 \pm 0.11$ and 5.98 \pm 0.018 ; respectively. While, the mean of $\mathrm{pH}$ values of samples treated with $1,1.5$ and $2 \%$ galangal oil in $10^{\text {th }}$ day were $6.67 \pm 0.31$, 
$6.4 \pm 0.05$ and $6.17 \pm 0.04$; respectively. Finally, the mean of $\mathrm{pH}$ values of samples treated with $1,1.5$ and $2 \%$ turmeric oil in $10^{\text {th }}$ day were $6.38 \pm 0.62$, $6.29 \pm 0.31$ and $6.05 \pm 0.002$; respectively. There were significant differences in the mean of $\mathrm{pH}$ value in different treatment samples during storage period at $(\mathrm{p}<0.05)$. As cleared from results listed in Table (3) $\mathrm{pH}$ values of all treated samples were lower than $\mathrm{pH}$ value of control samples in the same times of examination, that might be due to the antimicrobial effect antioxidant compounds such phenolic and flavonoids in essential oils of plants. Aureli et al., (1992) suggested that the increased $\mathrm{pH}$ value of meat might be due to the effect of microbial growth which may cause protein hydrolysis and release of nitrogenous compounds that increase the $\mathrm{pH}$ value of meat. As observed from the same table the more essential oil was concentrated, the less $\mathrm{pH}$ value would be. For example the treated minced meat by essential oil $2 \%$ concentration had lower $\mathrm{pH}$ value than that was treated by 1 or $1.5 \%$, similar finding was obtained by ALsaiqali et al., (2016) whom indicated that the high concentration of essential oils reduced the values of $\mathrm{pH}$. Also, the obtained results in Table (3) showed that essential oil of ginger was the more effective for lowing $\mathrm{pH}$ values, followed by turmeric essential oils and finally galangal essential oils. Such results were in agreed with those were obtained by Kassem et al., (2011); Shaltout et al., (2017).

Table (3): Effect of different concentrations of (ginger, galangal and turmeric) essential oils on $\mathrm{pH}$ values of untreated and treated samples

\begin{tabular}{|c|c|c|c|c|c|c|}
\hline \multirow{2}{*}{\multicolumn{2}{|c|}{ Sample }} & \multicolumn{5}{|c|}{ Mean of $\mathrm{pH}$ values of samples in different times of examination } \\
\hline & & $\mathbf{1}^{\text {st }}$ day & $3^{\text {rd day }}$ & $5^{\text {th }}$ day & $7^{\text {th }}$ day & $10^{\text {th }}$ day \\
\hline \multicolumn{2}{|c|}{ Control } & $5.5 \pm 0.01$ & $5.97 \pm 0.002^{\mathrm{a}}$ & $6.31 \pm 0.02^{\mathrm{a}}$ & $6.65 \pm 0.007^{\mathrm{a}}$ & $6.82 \pm 0.19^{\mathrm{a}}$ \\
\hline \multirow{3}{*}{ 离 } & $1 \%$ & $5.5 \pm 0.01$ & $5.83 \pm 0.03^{\mathrm{bc}}$ & $6.01 \pm 0.11^{\mathrm{cd}}$ & $6.21 \pm 0.05^{\mathrm{c}}$ & $6.38 \pm 0.02^{\mathrm{bc}}$ \\
\hline & $1.5 \%$ & $5.5 \pm 0.01$ & $5.77 \pm 0.01^{\mathrm{cd}}$ & $5.91 \pm 0.02^{\mathrm{d}}$ & $6.12 \pm 0.01^{\mathrm{cd}}$ & $6.22 \pm 0.11^{\mathrm{c}}$ \\
\hline & $2 \%$ & $5.5 \pm 0.01$ & $5.54 \pm 0.06^{\mathrm{e}}$ & $5.69 \pm 0.03^{\mathrm{a}}$ & $5.88 \pm 0.02^{\mathrm{e}}$ & $5.98 \pm 0.018^{\mathrm{d}}$ \\
\hline \multirow{3}{*}{ 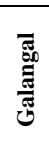 } & $1 \%$ & $5.5 \pm 0.01$ & $5.90 \pm 0.11^{\mathrm{ab}}$ & $6.27 \pm 0.03^{\mathrm{a}}$ & $6.59 \pm 0.07^{\mathrm{a}}$ & $6.67 \pm 0.31^{\mathrm{a}}$ \\
\hline & $1.5 \%$ & $5.5 \pm 0.01$ & $5.82 \pm 0.02^{\mathrm{a}}$ & $6.11 \pm 0.002^{\mathrm{bc}}$ & $6.34 \pm 0.21^{b}$ & $6.40 \pm 0.05^{\mathrm{b}}$ \\
\hline & $2 \%$ & $5.5 \pm 0.01$ & $5.77 \pm 0.24^{\mathrm{cd}}$ & $6.06 \pm 0.07^{b}$ & $6.15 \pm 0.04^{\text {cd }}$ & $6.17 \pm 0.04^{\text {cd }}$ \\
\hline \multirow{3}{*}{ 苞 } & $1 \%$ & $5.5 \pm 0.01$ & $5.85 \pm 0.51^{\mathrm{b}}$ & $6.18 \pm 0.21^{\mathrm{ab}}$ & $6.30 \pm 0.01^{\mathrm{bc}}$ & $6.43 \pm 0.62^{b}$ \\
\hline & $1.5 \%$ & $5.5 \pm 0.01$ & $5.81 \pm 0.07^{\mathrm{bc}}$ & $6.03 \pm 0.003^{\text {cd }}$ & $6.17 \pm 0.12^{\mathrm{cd}}$ & $6.29 \pm 0.31^{\mathrm{bc}}$ \\
\hline & $2 \%$ & $5.5 \pm 0.01$ & $5.68 \pm 0.21^{\mathrm{d}}$ & $5.73 \pm 0.04^{\mathrm{e}}$ & $6.06 \pm 0.11^{\mathrm{d}}$ & $6.05 \pm 0.002^{\text {cd }}$ \\
\hline
\end{tabular}

\section{Effect of different concentrations of (ginger, galangal and turmeric) essential oils on total aerobic plate count of untreated and treated minced meat samples}

The standard aerobic plate count (APC) of mesophilic bacteria was a rough measure of the bacteria content and the sanitary conditions during processing or temperature abuses of food (Daoud et al., 1995). From the data listed in Table (4) it could be observed that the examined samples had a moderated microbial value in primary samples. The mean value of APC of purchased minced meat before treated was $2.3 \times 10^{5} \pm 4.24 \mathrm{cfu} / \mathrm{g}$. As showed in Table (4) the mean values of APC of control sample increased from $2.3 \times 10^{5} \pm 4.24$ to $3.1 \times 10^{9} \pm 4.6 \mathrm{cfu} / \mathrm{g}$ throughout the storage period. All concentrations of the three plants extractions possessed antimicrobial activity 
aerobic bacteria. Essential oil of ginger extraction had the highest efficiency against bacteria. Such results were closed with that obtained by UkaegbuObir et al., (2016). Results clearly showed that the mean values of APC of treated samples with $1,1.5$ and $2 \%$ ginger extracts in $10^{\text {th }}$ day were $5.4 \times 10^{7} \pm 3.8, \quad 2.1 \times 10^{7} \pm 5.17$ and $3.3 \times 10^{6} \pm 6.86 \mathrm{cfu} / \mathrm{g} ;$ respectively. The current results were agreed with those obtained by Kullanitpitch et al., (2015). Essential oil of turmeric extraction had higher efficiency against bacteria than that of galangal. The mean values of APC of treated samples with $1,1.5$ and $2 \%$ turmeric extracts in $10^{\text {th }}$ day were $6.8 \times 10^{7} \pm 3.63,3.2 \times 10^{7} \pm 4.55$ and $5.7 \times 10^{6} \pm 6.24 \mathrm{cfu} / \mathrm{g}$; respectively. While, The mean values of APC of treated samples with $1,1.5$ and $2 \%$ galangal extracts in $10^{\text {th }}$ day were $1.7 \times 10^{8} \pm 2.11$, $3.8 \times 10^{7} \pm 4.09$ and $1.2 \times 10^{7} \pm 5.15 \mathrm{cfu} / \mathrm{g}$; respectively. The varying degrees of sensitivity of the bacterial test organisms may be due to both the intrinsic tolerance of microorganisms and the nature and combinations of phytocompounds present in the essential oil as recorded by Natta et al., (2008).

Table (4): Effect of different concentrations of (ginger, galangal and turmeric) essential oils on total aerobic plate count (APC) of untreated and treated samples

\begin{tabular}{|c|c|c|c|c|c|c|}
\hline \multirow{2}{*}{\multicolumn{2}{|c|}{ Sample }} & \multicolumn{5}{|c|}{ Total aerobic count $\left(\log \mathrm{cfu} . \mathrm{g}^{-1}\right)$ in different times of examination } \\
\hline & & $\mathbf{1}^{\text {st }}$ day & $3^{\text {rd }}$ day & $5^{\text {th }}$ day & $7^{\text {th }}$ day & $10^{\text {th }}$ day \\
\hline \multicolumn{2}{|c|}{ Control } & $2.3 \times 10^{5} \pm 4.24$ & $7.3 \times 10^{6} \pm 3.33^{\mathrm{a}}$ & $7.8 \times 10^{7} \pm 4.02^{\mathrm{a}}$ & $2.8 \times 10^{8} \pm 3.80^{\mathrm{a}}$ & $3.1 \times 10^{9} \pm 4.6^{\mathrm{a}}$ \\
\hline \multirow{3}{*}{ 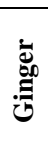 } & $1 \%$ & $2.3 \times 10^{5} \pm 4.24$ & $3.4 \times 10^{5} \pm 2.32^{\mathrm{d}}$ & $5.2 \times 10^{6} \pm 3.78^{b}$ & $7.1 \times 10^{6} \pm 2.32^{\mathrm{c}}$ & $5.4 \times 10^{7} \pm 3.8 \mathrm{c}$ \\
\hline & $1.5 \%$ & $2.3 \times 10^{5} \pm 4.24$ & $3.1 \times 10^{5} \pm 2.88^{\mathrm{d}}$ & $4.4 \times 10^{6} \pm 4.30^{\mathrm{c}}$ & $5.2 \times 10^{6} \pm 4.74^{\mathrm{d}}$ & $2.1 \times 10^{7} \pm 5.17^{\mathrm{d}}$ \\
\hline & $2 \%$ & $2.3 \times 10^{5} \pm 4.24$ & $2.6 \times 10^{5} \pm 1.26^{\mathrm{e}}$ & $7.6 \times 10^{5} \pm 2.91^{\mathrm{d}}$ & $1.2 \times 10^{6} \pm 2.49^{\mathrm{e}}$ & $3.3 \times 10^{6} \pm 6.86^{\mathrm{e}}$ \\
\hline \multirow{3}{*}{ 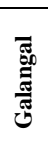 } & $1 \%$ & $2.3 \times 10^{5} \pm 4.24$ & $6.4 \times 10^{5} \pm 6.01^{\mathrm{b}}$ & $6.6 \times 10^{6} \pm 3.63^{b}$ & $2.7 \times 10^{7} \pm 2.43^{b}$ & $1.7 \times 10^{8} \pm 2.11^{\mathrm{b}}$ \\
\hline & $1.5 \%$ & $2.3 \times 10^{5} \pm 4.24$ & $4.8 \times 10^{5} \pm 4.5^{\mathrm{c}}$ & $4.7 \times 10^{6} \pm 4.06^{\mathrm{c}}$ & $7.3 \times 10^{6} \pm 2.92^{\mathrm{c}}$ & $3.8 \times 10^{7} \pm 4.09^{d}$ \\
\hline & $2 \%$ & $2.3 \times 10^{5} \pm 4.24$ & $2.8 \times 10^{5} \pm 3.03^{\mathrm{e}}$ & $3.4 \times 10^{6} \pm 2.28^{\mathrm{c}}$ & $5.4 \times 10^{6} \pm 4.34^{\mathrm{d}}$ & $1.2 \times 10^{7} \pm 5.15^{d}$ \\
\hline \multirow{3}{*}{ 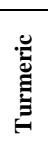 } & $1 \%$ & $2.3 \times 10^{5} \pm 4.24$ & $4.4 \times 10^{5} \pm 2.81^{\mathrm{c}}$ & $6.2 \times 10^{6} \pm 3.36^{\mathrm{b}}$ & $1.4 \times 10^{7} \pm 5.31^{b}$ & $6.8 \times 10^{7} \pm 3.63^{\mathrm{c}}$ \\
\hline & $1.5 \%$ & $2.3 \times 10^{5} \pm 4.24$ & $3.4 \times 10^{5} \pm 2.62^{d}$ & $4.1 \times 10^{6} \pm 2.25^{\mathrm{c}}$ & $6.8 \times 10^{6} \pm 1.94^{\mathrm{c}}$ & $3.2 \times 10^{7} \pm 4.55^{d}$ \\
\hline & $2 \%$ & $2.3 \times 10^{5} \pm 4.24$ & $2.9 \times 10^{5} \pm 2.32^{\mathrm{e}}$ & $6.3 \times 10^{5} \pm 3.42^{\mathrm{d}}$ & $2.4 \times 10^{6} \pm 3.43^{\mathrm{e}}$ & $5.7 \times 10^{6} \pm 6.24^{\mathrm{e}}$ \\
\hline
\end{tabular}

Effect of different concentrations of (ginger, galangal and turmeric) essential oils on total Sylococcus aureus count of untreated and treated minced meat samples

Sylococcus aureus is the type species of the genus Sylococcus, which occurs as gram positive and catalase positive cocci (ICMSF, 1996). Table (5) illustrated that the mean value of total $S$. aureus of all investigated samples in beginning was $1.1 \times 10^{2} \pm 3.83 \mathrm{cfu} / \mathrm{g}$. All concentrations of the 3 plants extractions possessed antimicrobial activity against $S$. aureus. The mean values of total $S$. aureus count of control sample throughout the storage period were $4.6 \times 10^{3} \pm 3.14, \quad 5.3 \times 10^{4} \pm 3.33, \quad 4.2 \times 10^{5} \pm 1.91$ and $3.9 \times 10^{6} \pm 4.07$ $\mathrm{cfu} / \mathrm{g}$ in $3^{\text {rd }}, 5^{\text {th }}, 7^{\text {th }}$ and $10^{\text {th }}$ day of the storage period; respectively. Data in Table (5) showed that essential oil of ginger had the highest efficiency against of $S$. aureus. Whereas, the essential oil of ginger successfully decreased the growth of $S$. aureus in treated minced meat with their essential oils. Such results were in agreement with that obtained by Krittika et al., (2007); Natta et al., (2008). Also, results indicated that the high concentration of ginger essential oils (2\%) reduced the growth of $S$. aureus 
highly. The mean values of total $S$. aureus count of treated samples with 1 , 1.5 and $2 \%$ ginger extracts in $10^{\text {th }}$ day were $4.3 \times 10^{4} \pm 2.82,1.5 \times 10^{4} \pm 2.66$ and $2.2 \times 10^{3} \pm 3.13 \mathrm{cfu} / \mathrm{g} ;$ respectively. Essential oil of galangal had the lowest efficiency against of $S$. aureus compared to those extracted from ginger and turmeric. The mean values of total $S$. aureus count of treated samples with 1 , 1.5 and $2 \%$ galangal extracts in $10^{\text {th }}$ day were $1.5 \times 10^{5} \pm 4.24,6.2 \times 10^{4} \pm 1.08$ and $4.8 \times 10^{4} \pm 4.21 \mathrm{cfu} / \mathrm{g}$; respectively. These results compatible with those were obtained by Oonmetta-aree et al. (2006). Essential oil of turmeric possessed good efficiency against of $S$. aureus. The mean values of total $S$. aureus count of treated samples with $1,1.5$ and $2 \%$ turmeric extracts in $10^{\text {th }}$ day were $5.2 \times 10^{4} \pm 3.08,3.7 \times 10^{4} \pm 2.17$ and $4.2 \times 10^{3} \pm 3.01 \mathrm{cfu} / \mathrm{g} ;$ respectively. In agreement with such results that reported by Mohd et al., (2015).

Table (5): Effect of different concentrations of (ginger, galangal and turmeric) essential oils on total Sylococcus aureus count of untreated and treated samples

\begin{tabular}{|c|c|c|c|c|c|c|}
\hline \multirow{2}{*}{\multicolumn{2}{|c|}{ Sample }} & \multicolumn{5}{|c|}{ Total Sylococcus aureus count $\left(\log\right.$ cfu. $\left.\mathrm{g}^{-1}\right)$ in different times of examination } \\
\hline & & $1^{\text {st }}$ day & $3^{\text {rd }}$ day & $5^{\text {th }}$ day & $7^{\text {th }}$ day & $10^{\text {th }}$ day \\
\hline \multicolumn{2}{|c|}{ Control } & $1.1 \times 10^{2} \pm 3.83$ & $4.6 \times 10^{3} \pm 3.14^{\mathrm{a}}$ & $5.3 \times 10^{4} \pm 3.33^{\mathrm{a}}$ & $4.2 \times 10^{5} \pm 1.91^{\mathrm{a}}$ & $3.9 \times 10^{6} \pm 4.07^{\mathrm{a}}$ \\
\hline \multirow{3}{*}{ 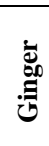 } & $1 \%$ & $1.1 \times 10^{2} \pm 3.83$ & $4.1 \times 10^{2} \pm 2.26^{b}$ & $3.7 \times 10^{3} \pm 1.04^{b}$ & $3.2 \times 10^{4} \pm 1.03^{b}$ & $4.3 \times 10^{4} \pm 2.82^{\mathrm{c}}$ \\
\hline & 1.5 & $1.1 \times 10^{2} \pm 3.83$ & $3.7 \times 10^{2} \pm 7.17^{\mathrm{b}}$ & $2.1 \times 10^{3} \pm 4.11^{\mathrm{c}}$ & $2.4 \times 10^{3} \pm 3.36^{\mathrm{c}}$ & $1.5 \times 10^{4} \pm 2.66^{\mathrm{d}}$ \\
\hline & $2 \%$ & $1.1 \times 10^{2} \pm 3.83$ & $1.9 \times 10^{2} \pm 3.20^{\mathrm{c}}$ & $5.2 \times 10^{2} \pm 0.19^{\mathrm{e}}$ & $1.9 \times 10^{3} \pm 2.44^{\mathrm{d}}$ & $2.2 \times 10^{3} \pm 3.13^{\mathrm{e}}$ \\
\hline \multirow{3}{*}{ 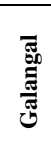 } & $1 \%$ & $1.1 \times 10^{2} \pm 3.83$ & $5.8 \times 10^{2} \pm 3.04^{\mathrm{b}}$ & $5.4 \times 10^{3} \pm 3.73^{b}$ & $3.5 \times 10^{4} \pm 2.21^{\mathrm{b}}$ & $1.5 \times 10^{5} \pm 4.24^{b}$ \\
\hline & 1.5 & $1.1 \times 10^{2} \pm 3.83$ & $4.4 \times 10^{2} \pm 1.73^{b}$ & $3.2 \times 10^{3} \pm 2.44^{\mathrm{c}}$ & $1.4 \times 10^{4} \pm 4.21^{b}$ & $6.2 \times 10^{4} \pm 1.08^{\mathrm{c}}$ \\
\hline & $2 \%$ & $1.1 \times 10^{2} \pm 3.83$ & $2.7 \times 10^{2} \pm 5.4^{\mathrm{c}}$ & $1.7 \times 10^{3} \pm 3.31^{\mathrm{c}}$ & $3.6 \times 10^{3} \pm 2.02^{\mathrm{c}}$ & $4.8 \times 10^{4} \pm 4.21^{\mathrm{c}}$ \\
\hline \multirow{3}{*}{ 参 } & $1 \%$ & $1.1 \times 10^{2} \pm 3.83$ & $4.9 \times 10^{2} \pm 1.16^{b}$ & $4.4 \times 10^{3} \pm 2.06^{b}$ & $2.4 \times 10^{4} \pm 3.32^{b}$ & $5.2 \times 10^{4} \pm 3.08^{\mathrm{c}}$ \\
\hline & 1.5 & $1.1 \times 10^{2} \pm 3.83$ & $3.9 \times 10^{2} \pm 1.12^{\mathrm{b}}$ & $2.3 . \times 10^{3} \pm 3.43^{\mathrm{c}}$ & $4.2 \times 10^{3} \pm 1.19^{\mathrm{c}}$ & $3.7 \times 10^{4} \pm 2.17^{\mathrm{d}}$ \\
\hline & $2 \%$ & $1.1 \times 10^{2} \pm 3.83$ & $2.2 \times 10^{2} \pm 1.25^{\mathrm{c}}$ & $1.3 \times 10^{3} \pm 2.21^{\mathrm{d}}$ & $3.1 \times 10^{3} \pm 1.99^{\mathrm{c}}$ & $4.2 \times 10^{3} \pm 3.01^{\mathrm{e}}$ \\
\hline
\end{tabular}

Data followed by different letters in the same column are significantly different at $p \leq 0.05$

Effect of different concentrations of (ginger, galangal and turmeric) essential oils on total $E$. coli count of untreated and treated minced meat samples

Data in Table (6) pointed that the total E. coil count of control sample was more compared with samples with $1,1.5$ or $2 \%$ ginger, galangal or turmeric extracts. The mean value of total E. coli of all investigated samples in beginning was $2.5 \times 10^{2} \pm 4.19 \mathrm{cfu} / \mathrm{g}$. Debbarma et al., (2012) reported that ginger essential oils have antibacterial activity on $E$. coli. The serogroups and the zingiberaceous extracts seemed to have an impact on the antimicrobial activity (Habsah et al., 2000; Indu et al., 2006). After 10 days storage period, the total E. coil count of treated samples with 1, 1.5 and $2 \%$ ginger extracts were $3.3 \times 10^{5} \pm 3.63,5.6 \times 10^{4} \pm 3.78$ and $3.9 \times 10^{4} \pm 4.02 \mathrm{cfu} / \mathrm{g}$. Nader et al., (2010) indicated that the ginger extracts were more effective on gram positive bacteria ( $S$. aureus) than on gram negative bacteria (E. coli), that probably due to the differences in cell wall structure of gram-positive bacteria and gram negative bacteria. The galangal essential oil showed antimicrobial activity against $E$. coli. The total $E$. coil count of treated samples with $1,1.5$ and $2 \%$ galangal extracts after 10 days storage period were $4.8 \times 10^{5} \pm 3.22, \quad 6.9 \times 10^{4} \pm 2.81$ and $2.9 \times 10^{4} \pm 3.06 \mathrm{cfu} / \mathrm{g}$. similar finding 


\section{Amany A. Abd El-Aziz}

was obtained by Watcharaporn and Nakanyapatthara, (2014). Data in Table (6) showed that essential oil of turmeric had the highest efficiency against of E. coli. The total E. coil count of treated samples with $1,1.5$ and $2 \%$ turmeric extracts after 10 days storage period were $2.5 \times 10^{5} \pm 5.27$, $4.5 \times 10^{4} \pm 3.04$ and $2.3 \times 10^{4} \pm 3.31 \mathrm{cfu} / \mathrm{g}$. Such results were agreed with those of Zeayd, (2014); who recorded that high concentrations of turmeric had a greater antiseptic property for E. coli. Also results were closed with those were obtained by Parveen and Jehan, (2015) who revealed that different extracts of turmeric had antimicrobial activity against Escherichia coli produced different zones of inhibition.

Table (6): Effect of different concentrations of (ginger, galangal and turmeric) essential oils on total $E$. coli count of untreated and treated samples

\begin{tabular}{|c|c|c|c|c|c|c|}
\hline \multirow{2}{*}{\multicolumn{2}{|c|}{ Sample }} & \multicolumn{5}{|c|}{ Total $E$. coli count $\left(\log\right.$ cfu. $\left.\mathrm{g}^{-1}\right)$ in different times of examination } \\
\hline & & $\mathbf{1}^{\text {st }}$ day & $3^{\text {rd }}$ day & $5^{\text {th }}$ day & $7^{\text {th }}$ day & $10^{\text {th }}$ day \\
\hline \multicolumn{2}{|c|}{ Control } & $2.5 \times 10^{2} \pm 4.19$ & $7.4 \times 10^{3} \pm 5.33^{\mathrm{a}}$ & $6.5 \times 10^{4} \pm 4.01^{\mathrm{a}}$ & $3.2 \times 10^{5} \pm 3.87^{\mathrm{a}}$ & $5.1 \times 10^{6} \pm 4.20^{\mathrm{a}}$ \\
\hline \multirow{3}{*}{ 离 } & $1 \%$ & $2.5 \times 10^{2} \pm 4.19$ & $6.8 \times 10^{2} \pm 3.93^{\mathrm{b}}$ & $4.5 \times 10^{3} \pm 3.36^{\mathrm{b}}$ & $5.8 \times 10^{4} \pm 2.23^{\mathrm{b}}$ & $3.3 \times 10^{5} \pm 3.63^{\mathrm{b}}$ \\
\hline & $1.5 \%$ & $2.5 \times 10^{2} \pm 4.19$ & $4.9 \times 10^{2} \pm 5.25^{\mathrm{c}}$ & $2.9 \times 10^{3} \pm 2.92^{\mathrm{c}}$ & $5.9 \times 10^{3} \pm 5.01^{\mathrm{c}}$ & $5.6 \times 10^{4} \pm 3.78^{c}$ \\
\hline & $2 \%$ & $2.5 \times 10^{2} \pm 4.19$ & $4.1 \times 10^{2} \pm 4.14^{\mathrm{c}}$ & $2.2 \times 10^{3} \pm 4.03^{\mathrm{c}}$ & $6.3 \times 10^{3} \pm 2.62^{\mathrm{c}}$ & $3.9 \times 10^{4} \pm 4.02^{\mathrm{c}}$ \\
\hline \multirow{3}{*}{ 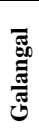 } & $1 \%$ & $2.5 \times 10^{2} \pm 4.19$ & $8.1 \times 10^{2} \pm 5.23^{b}$ & $5.2 \times 10^{3} \pm 4.11^{\mathrm{b}}$ & $6.3 \times 10^{4} \pm 1.61^{\mathrm{b}}$ & $4.8 \times 10^{5} \pm 3.22^{b}$ \\
\hline & $1.5 \%$ & $2.5 \times 10^{2} \pm 4.19$ & $5.3 \times 10^{2} \pm 3.78^{b}$ & $4.1 \times 10^{3} \pm 3.07^{\mathrm{b}}$ & $1.1 \times 10^{4} \pm 2.96^{\mathrm{b}}$ & $6.9 \times 10^{4} \pm 2.81^{\mathrm{b}}$ \\
\hline & $2 \%$ & $2.5 \times 10^{2} \pm 4.19$ & $4.9 \times 10^{2} \pm 2.62^{\mathrm{c}}$ & $2.8 \times 10^{3} \pm 4.91^{\mathrm{c}}$ & $4.3 \times 10^{3} \pm 4.08^{\mathrm{c}}$ & $2.9 \times 10^{4} \pm 3.06^{\mathrm{c}}$ \\
\hline \multirow{3}{*}{ 总 } & $1 \%$ & $2.5 \times 10^{2} \pm 4.19$ & $6.5 \times 10^{2} \pm 3.53^{\mathrm{c}}$ & $3.7 \times 10^{3} \pm 3.63^{\mathrm{c}}$ & $4.1 \times 10^{4} \pm 4.34^{b}$ & $2.5 \times 10^{5} \pm 5.27^{b}$ \\
\hline & $1.5 \%$ & $2.5 \times 10^{2} \pm 4.19$ & $4.6 \times 10^{2} \pm 5.21^{\mathrm{c}}$ & $2.4 \times 10^{3} \pm 4.01^{\mathrm{c}}$ & $5.1 \times 10^{3} \pm 2.17^{\mathrm{c}}$ & $4.5 \times 10^{4} \pm 3.04^{c}$ \\
\hline & $2 \%$ & $2.5 \times 10^{2} \pm 4.19$ & $3.8 \times 10^{2} \pm 2.42^{\mathrm{d}}$ & $1.7 \times 10^{3} \pm 3.46^{\mathrm{d}}$ & $4.7 \times 10^{3} \pm 3.53^{\mathrm{c}}$ & $2.3 \times 10^{4} \pm 3.31^{\mathrm{c}}$ \\
\hline
\end{tabular}

Data followed by different letters in the same column are significantly different at $\mathrm{p} \leq 0.05$

\section{Conclusion}

Generally, according to this study it could be concluded that essential oils of ginger, galangal and turmeric and their extracts had good antimicrobial potential in addition to the antioxidants and anticancer effects. Such substances can be used as effective natural additives instead of synthetic substances. These substances are had beneficial effects to extend the shelf life of meat and their products by controlling/inhibition the microbial growth.

\section{References}

Adel, S. P. R. and Prakash, J. (2010). Chemical composition and antioxidant properties of ginger root (Zingiber officinale). J. of Medicinal Plants Res. 4(24): 2674-9. 


\section{Amany A. Abd El-Aziz}

A.O.A.C. (2000). Official methods of analysis. Arlington, USA, Association of Official Analytical Chemists.

A.O.A.C. (2010). Association of Official Analytical Chemists. Official method of analysis 19th ed. Gaithersburg, MD, USA.

Alsaiqali, M.; El-Shibiny, A.A.; Adel, M. Abdel-Samie, M.A.S. and Ghoneim, S. (2016). Use of Some Essential Oils as Antimicrobial Agents to Control Pathogenic Bacteria in Beef Burger. World J. of Dairy \& Food Sci. 11(1): 109120.

Aureli, p.; Costantini, A. and Zolea, S. (1992). Antimicrobial activity of some plant essential oils against Listeria monocytogenes. J. Food Port., 55(5):344-8.

Bartley, J. and Jacobs, A. (2000). Effects of drying on flavour compounds in Australian-grown ginger (Zingiber officinale). J. Sci. Food Agric., 80(2): 20915.

Bell, R. G. (1997). Distribution and sources of microbial contamination onbeef carcasses. J. Appl. Microobiol., 82, 292-300.

Charles, D. J.; Morales, R. and Simon, E. (1993). Essential oil content and chemical composition of hydroalcoholic extract of fennel, New crop, 570-3.

Coakes S., (2005). SPSS: Analysis without Anguish version 12.0 for windows. Singapore, CMO Image Printing Enterprise.

Daoud S.A., Ghoneim E.H., and Hamza A.S. (1995). Study of the chemical composition, some contaminants and bacterial contents of some local meat products. J. Agri. Sci. Mansoura University. 20(10): 4409-18.

Debbarma, J.; Kishore, P.; Nayak, B. B.; Kannuchamy, N. and Gudipati, V. (2012). Antibacterial activity of ginger, eucalyptus and sweet orange peel essential oils on fish-borne bacteria. J. Food Process Pres. (37): 1022-30.

Dowdy S., Wearon S. and Chilko D. (2004). Statistic for Reasearch. 3rd Ed, New Jersey, A John Wiley \& Song, Inc. 265-72.

Edeoga, H. O.; Okwu, D. E. and Mbaeble, B. O. (2005). Phytochemical Constituents of Some Nigerian Medicinal Plants, African Journal of Biotechnology, Vol.4 (7): 685-8.

Ekop, E.; Udoh, A. and Akpan, P. E. (2010). Proximate and anti-nutrient composition of four edible insects In Akwa Ibom State, Nigeria. World J. Applied Sci. and Tech., 2(2): $224-231$.

El-Ghorab, A. H; Nauman, M.; Anjum, F. M.; Hussain, S. and Haddem, M. (2010). A Comparative Study on Chemical Composition and Antioxidant Activity of Ginger (Zingiber officinale) and Cumin (Cuminum cyminum). J. Agric. Food Chem. 58: 8231-7.

Elmalı, M. and Yaman, H. (2005). Microbiological quality of raw meat balls: produced and sold in the eastern of Turkey. Pakistan J Nutr, 4 (4): 197-201.

El-Sherbeeny Z., (1995). Statistics and design experiments in psychological research, educational and social. 1st Ed, El-Anglo, Cairo, Egypt. pp: 126-50, 203-5 and 220-5. 


\section{Amany A. Abd El-Aziz}

Fattepurkar, S. C.; Damame, S. V. and Ghadge, S. N. (2009). Chemical composition of finger rhizomes of Curcuma aromatic L. and Curcuma longa L. The Asian J. of Experimental Chem. 4(1,2): 84-6.

Habsah, M.; Amran, M.; Mackeen, M. M.; Lajis, N. H.; Kikuzaki, H.; Nakatani, H.; Rahman, A.; Ghafar, A. and Ali, A. M. (2000). Screening of Zingiberaceae extracts for antimicrobial and antioxidant activities. J Ethnopharmacol 72:403-10.

Hashemi, S. R.; Zulkifli, I.; Hair Beijo, M.; Farida, A. and Somchit, N. M. (2008). Acute toxicity study and phytochemical screening of selected herbal aqueous extract in broiler chickens. Inter. J. of Pharm., 4(5): 352-60.

Hussain, J.; Bahader, A.; Ullah, F.; Rehman, N.; Khan, A., Ullah, W. and Shinwari, Z. (2009). Proximate and nutrient analysis of the locally manufactured herbal and its raw material. J. Am. Sci., 5(6): 1-5.

ICMSF Bulletien, (1996). International Commission on Microbiological Specifications of Foods. Microorganism in foods,: Microbiological specifications of food pathogens. 1st Ed. Blackie Academic and professional, London.

Indu, M.; Hatha, A.; Abirosh, C.; Harsha, U. and Vivekanandan G. (2006). Antimicrobial activity of some of the south-Indian spices against serotypes of Escherichia coli, Salmonella, Listeria monocytogenes and Aeromonas hydrophila. Braz. J. Microbiol. 37:153-8.

Johnson, I. T.; Gee, J. M.; Price, K.; Curl, C. and Fenwick, G. R. (1986). Influence of saponin on gut permeability and active nutrient transport in vitro. 116: $2270-7$.

Kassem, G. M.; Atta-Alla, O. A. and Ali, F .H. M. (2011) Improving the quality of beef burger by adding thyme essential oil and jojoba oil. Arch Zootec 60: 78795 .

Kesavan, R.K.; Srinivasan, B.; Packirisamy, A. S.; Mohammed, A. F.; Kalleary, S, et al. (2014). Bio protection and preservation of raw beefmeat using pungent aromatic plant substances. J. Sci. Food Agric. 94: 2456-63.

Kirk, R. S. and Sawyer, R. (1991). Pearson's composition and analysis of foods, 9th end. Pp. 8-42. Essex.: Longman Scientific and Technical.

Krittika N.; Natta L. and Orapin K. (2007). Antibacterial Effect of Five Zingiberaceae Essential Oils. Molecules, 12(8): 2047-60.

Kullanitpitch, U.; Srunya, V. and Yingyong, P. (2015). Antibacterial Properties of the Extracts from Some Zingibereous Species in Thailand against Bacteria Causing Diarrhea and Food Poisoning in Human. Inter. Transaction J. of Eng., Management, \& Applied Sci. \&Technologies. 6(5): 203-13.

Maizura, M.; Aminah, A. and Wan Aida, W. M. (2011). Total phenolic content and antioxidant activity of kesum (Polygonum minus), ginger (Zingiber officinale) and turmeric (Curcuma longa) extract. International Food Research Journal 18: 526-31.

Matsuda, H.; Morikawa, T.; Sakamoto, Y.; Toguchida, I.; Yoshikawa, M. (2002). Effects on increase in vascular permeability and nitric oxide 
production from Hedychium coronarium. Labdane-type Diterpenes with Inhibitory. J. Bioorg Med. Chem. 10:2527-34.

Mohd, M. S.; Chin, L. L. and Sim, N. L. (2003). Antifungal activity of essential oil of nine Zingiberaceae spices. J. Pharm. Biol. 41(5): 302-7.

Mohd Khairul, A. B., Shafida, A. H. and Deny S. (2015). Chemical Composition and Antibacterial Activity of Essential Oils from Three Aromatic Plants of the Zingiberaceae Family in Malaysia.

Nader, M. I.; Ghanima, K. K.; Ali, A. S. and Azhar, D. A. (2010). Antibacterial activity of ginger extracts and its essential oil on some of pathogenic bacteria. Baghdad Sci. J. 7(3): 1159-65.

Natta, L.; Orapin, K.; Krittika, N. and Pantip, B. (2008). Essential oil from five Zingiberaceae for anti food-borne bacteria. Int. Food Res. J. 15(3): 337-46.

Nelson, M.; Jones, S. H.; Edwards, C. and Ellis, J. C. (2008). Characterization of Escherichia coli populations from gulls, landfill trash, and wastewater using ribotyping. Dis. Aquat. Org., 81, 53-63.

Noheer, G. E. (2018). Effect of galangal (Alpinia galangal) as consumption as antioxidants on hyperlipidemic and hyperglycemic (In experimental rats). Ph.D, Thesis, Home Economic Department, Faculty of Specific Education, Ain Shams Univ.

Norman, G. M. and Gravani, R. B. (2006). Principles of Food Sanitation. $5^{\text {th }}$ Edition, Springer, USA.

Oonmetta-aree, J., T. Suzuki, P. Gasaluck and G. Eumkeb. (2006). Antimicrobial properties and action of galangal (Alpinia galanga Linn.) on Sylococcus aureus. LWT, 39: 1214-20.

Parveen, G. and Jehan, B. (2015). Antimicrobial activity of turmeric extract and its potential use in food industry. J Food Sci Technol. 52(4): 2272-9.

Pulla, R. A. and Lokesh, B. R. (1992). Studies on spice principles as antioxidants in the inhibition of lipid peroxidation of rat liver microsomes. Mol Cell Biochem 111: 117-24.

Rababah, T.; Navam, S.; Hettiarachchy, A. and Ronny, H. (2004). Total phenolic and antioxidant activity of fenugreek, green tea, black tea, grape seed, ginger, rosemary, gotu kola and ginkgo extract, vitamin $\mathrm{E}$ and tertButylhydroquinone. J. Agri. Food Chem. 52: 5183-6.

Rajeev, S.; Pawan, K. V. and Gagandeep, S. (2012) Total phenolic, flavonoids and tannin contents in different extracts of Artemisia absinthium. J. Intercult Ethnopharmacol. 1 (2):101-4.

Salem, A. M.; Zakaria, E. M. and Abd El-Raheem K. A. (2017). Efficiency of some essential oils in control of methicillin resistant Sylococcus aureus (MRSA) in minced beef.

Shaltout, F. A. 1.; Thabet, M. G. and Koura, H. A. (2017). Impact of Some Essential Oils on the Quality Aspect and Shelf Life of Meat. J. Nutr. Food Sci., $7(6)$.

Shelef, L. A. and Jay, J. M. (1970). Use of titrimetric method to assess the bacterial spoilage of fresh beef. Appl. Microbial.19:902. 


\section{Amany A. Abd El-Aziz}

Suhaj, M. (2006). Spice antioxidants isolation and their antiradical activity: a review. J Food Compost Anal 19:531-7

Tripathi, M.; Chawla, P.; Upadhyay, R. and Trivedi, S. (2013). Essential Oils From Family Zingiberaceae for Antimicrobial Activity - A Review. Int.J. Pharm. Bio. Sci. 4(4): 149-62.

Turker, A. U. and Usta, C. Y. (2006). Biological activity of some medicinal plants sold in Turkish Health-Food Stores. Biotechnology and Biotechnological Equipment. 20(3): 105.

Ukaegbu-Obi, K. M.; Ifediora, A. C.; Ifediora, N. H. and Chukwu, B. (2016). In vitro combined antibacterial effect of turmeric (Curcuma longa) and ginger (Zingiber officinale) on some pathogenic organisms. Analele Universităţii din Oradea, Fascicula Biologie. XXIII(1): 32-6.

Vanderzant, C., \& Splittstoesser, D. F. (1992). Sylococcal enterotoxins. In R. W. Bennett, S. Notermans, \& S. R. Tatini (Eds.), Compendium of methods for the microbiological examination of foods, ( $3^{\text {rd }}$ ed) (pp. 5-51). American Public Health Association, WA: Print-Edwards Brothers.

Watcharaporn, S. and Nakanyapatthara, J. (2014). Effect of Alpinia galangal essential oil on bacteria spoilage. The $26^{\text {th }}$ Annual Meeting of the Thai Society for Biotechnology and International Conference.

Yang, X. and Eilerman, R.G. (1999). Pungent principle of Alpinia galanga (L.) Swartz and its application. J. Agric. Food Chem. 47: 1657-62.

Zeayd F. S. (2014). The Antiseptic Effect of Turmeric (Curcuma longa) Extraction on the Bacterial Growth of Escherichia Coli (K-12) and Salmonella Typhi which Cause Food Poisoning. J. OF Advances in Bio.4(3): 546-9.

Zheng, W. and Wang, S. (2001). Antioxidant activity and phenolic composition in selected herbs. Journal of Agricultural and Food Chemistry 49: 5165-70.

Zhishen, J.; Mengcheng, T. and Jianming, W. (1999). The determination of flavonoid contents in mulberry and their scavenging effects on superoxide radicals. Food Chem, 64: 555-9. 


\title{
Amany A. Abd El-Aziz
}

\section{تأثير بعض الزيوت العطرية للعائلة الزنجبيلية على محتوى البكتريا المسببة}

\section{لتلأمراض في اللحم المفروم}

\author{
أمانى أحمد عبد العزيز
}

قسم الاقتصاد المنزلي ، كلية التربية النوعية ، جامعة جنوب الوادي ، قنا ، مصر

تعتبر اللحوم ومنتجاتها منل اللحم المفروم من الأغذية الأكثر عرضة للتلف ويمكن أن تفسد ألفا

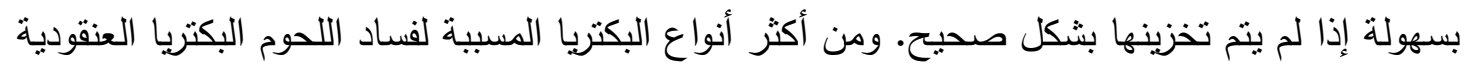

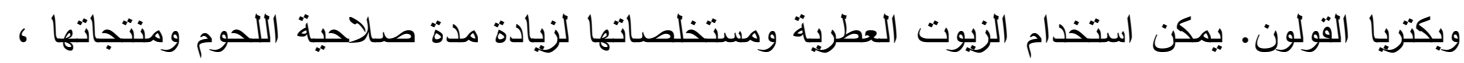
وتتبيط/وقف نمو الميكروبات. في الدراسة الحالية ، نم استخلاص الزيوت العطرية من ب أنواع من

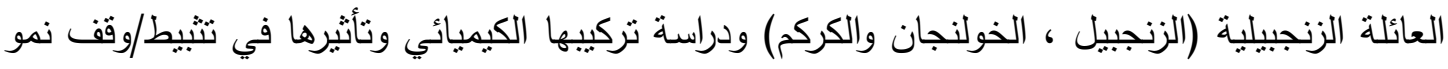
البكتيريا المسببة لفساد اللحم المفروم. تم شراء عينات من جذور الزنجبيل والخولنجان والكركم الطازجة ودئة

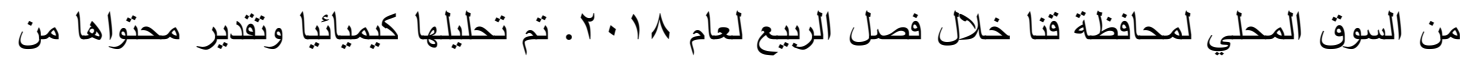

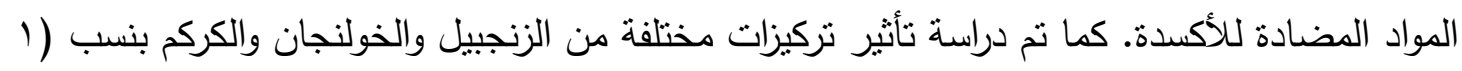

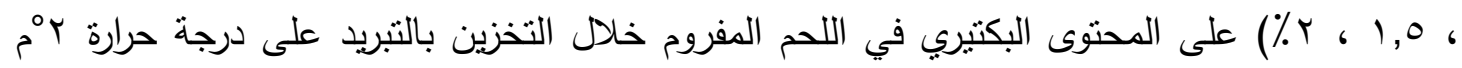

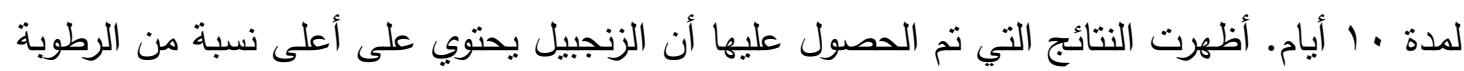

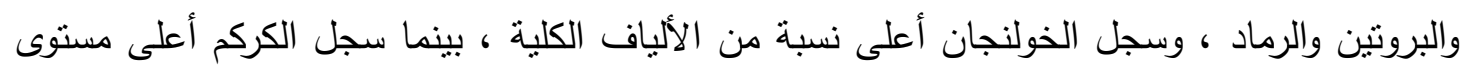

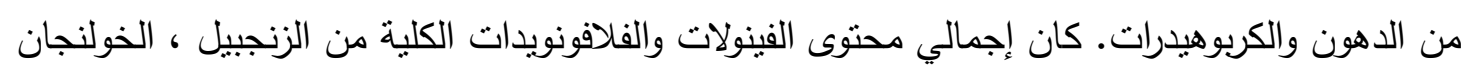

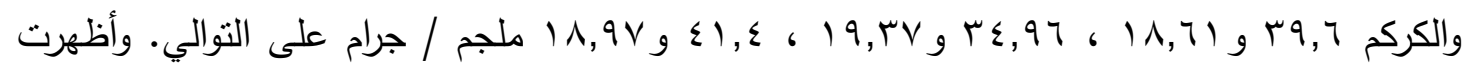
النتائج انخفاض العدد الكلي للميكروبات الهوائية وبكتريا القولون والبكتريا العنقودية في اللحم المفروم المعالج بمستخلصات النباتات محل الدراسة عن عينة اللحم غير المعاملة بأي اضافات (الضابطة) طوال فترة التجربة ، في حين كانت هنالك فروق ذات دلالة معنوية بين اللحم المفروم غير المعالجة

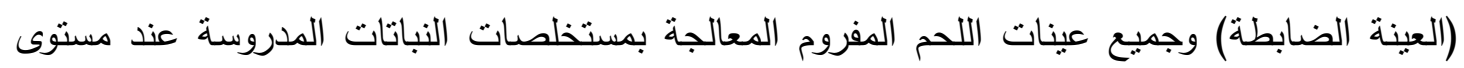

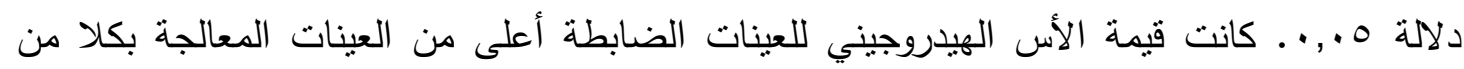

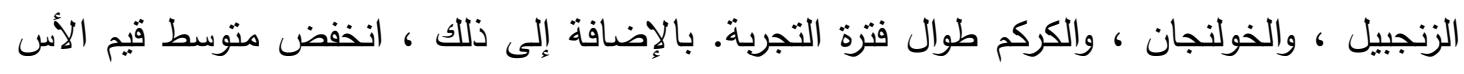

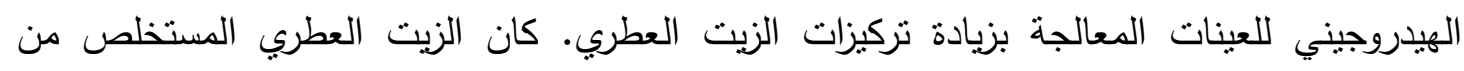

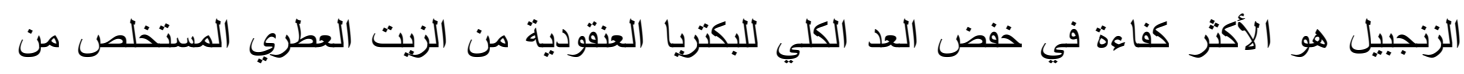

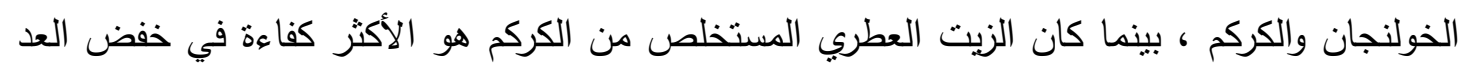

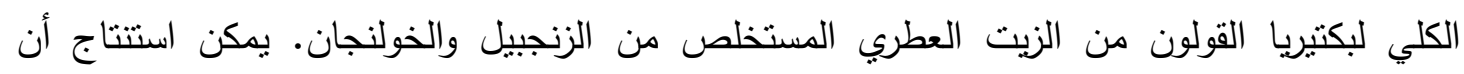
الزيوت العطرية المستخلصة من العائلة الزنجبيلية مثل الزنجبيل ، والخولنجان ، والكركم لها تأثير فعال

ومضاد للميكروبات بما بساعد على حفظ اللحوم ومنتجاتها من الفساد وإطالة فترة حفظها. الكلمات المفتاحية: الزيوت العطرية، المستخلصات، الزنجبيل، الخولنجان، الكركم، الفينولات الكلية، المحتوى الميكروبي، اللحوم المفرومة. 